American Journal of Applied Sciences 7 (8): 1115-1117, 2010

ISSN 1546-9239

(C) 2010 Science Publications

\title{
Fast Decoupled Power Flow for Power System with High Voltage Direct Current Transmission Line System
}

\author{
Prechanon Kumkratug \\ Division of Electrical Engineering, Faculty of Engineering at Si Racha, \\ Kasetsart University, 199 M.6, Tungsukhla, Si Racha, Chonburi, 20230, Thailand
}

\begin{abstract}
Problem statement: High voltage direct current transmission line system has been widely applied for control power flow in power system. The power flow analysis was the one of powerful tools by which the power system equipped was analyzed both for planning and operation strategies. Approach: This study presented the method to analyze power flow of power system consisted of HVDC system. HVDC was modeled as the complex power injections. The presented complex power injected was incorporated into the existing power flow program based on fast decoupled method. The presented method was tested on the multimachine power system. Results: The transmission line loss of the system with and without HVDC was compared. Conclusion: From the simulation results, the HVDC can reduce transmission line loss of power system.
\end{abstract}

Key words: Power system, power flow analysis, decoupled power, transmission line loss, multimachine system, proposed method

\section{INTRODUCTION}

High Voltage Direct Current (HVDC) transmission line system is getting more and more popular because of lower investment cost in long distance, lower losses, asynchronous interconnection between power systems, better controllable power flow compared with Alternating Current (AC) system (Al-Abdulaziz at al., 2006; Lu et al., 2006; Sun et al., 2008). The great important role of power flow analysis is to determine the operating point of the existing, study in planning the future expansion and evaluate the best operating point of power system (Ahmed at al., 2008; Al-Rawi at al., 2007; Augusto at al., 2008; Noor at al., 2008).

The objective of power flow analysis of the system equipped with HVDC system is to solve operating point both AC and HVDC system. In the performing power flow calculation of $\mathrm{AC}$ system on the nodal iterative method, two AC variables are specified while the remaining two AC variables are solved iteratively. There are many methods of power flow analysis (Parry and Gangatharan, 2005; Federico, 2009). The fast decoupled power flow provides rapid solution for power system with low resistance and susceptance ratio (Avakian at al., 2006). HVDC transmission line system is based on advanced power electronic technology. The parameter in HVDC side is the DC quantities. It is simultaneously solved the AC and DC parameters.

This study presents the power flow analysis of power system equipped with HVDC system. The presented mathematical model of HVDC system is incorporated into $\mathrm{AC}$ power flow analysis based on fast decoupled method. The simulation results are tested on multimachine system and compared with various cases.

\section{MATERIALS AND METHODS}

AC fast decoupled power flow: The fast decoupled power flow equations of solving unknown parameters of Voltage magnitude $(\mathrm{V})$ and angle $(\delta)$ are given by:

$$
\begin{aligned}
& \Delta \delta=-[\mathrm{B}]^{-1} \frac{\Delta \mathrm{P}}{\mathrm{V}} \\
& \Delta \mathrm{V}=-\left[\mathrm{B}^{\prime \prime}\right]^{-1} \frac{\Delta \mathrm{Q}}{\mathrm{V}}
\end{aligned}
$$

Here B' and B" are the imaginary part of bus admittance. $\mathrm{P}$ and $\mathrm{Q}$ are the active and reactive power injection at $\mathrm{AC}$ system.

HVDC model: Figure 1a shows the schematic diagram of HVDC system. The equivalent circuit of Fig. 1a is shown in Fig. 1b. The subscripts represent the sending quantities end and the subscripts ' $r$ ' represents the receiving end parameters. The converter can be represented by the variable DC voltage source $\left(\mathrm{V}_{\mathrm{d}}\right)$ and constant resistance $\left(\mathrm{R}_{\mathrm{C}}\right)$. The DC transmission line is represented by constant resistance $\mathrm{R}_{\mathrm{L}}$. 


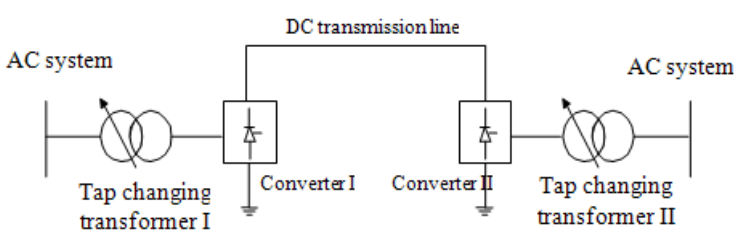

(a)

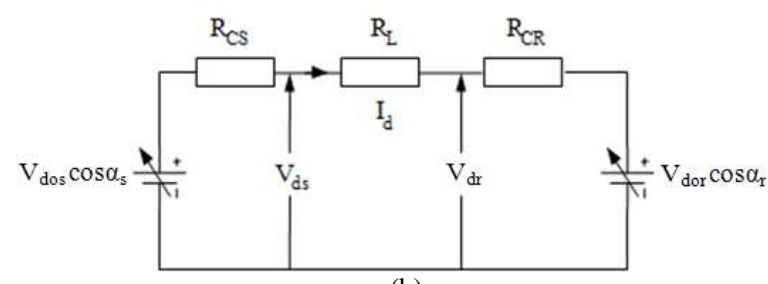

(b)

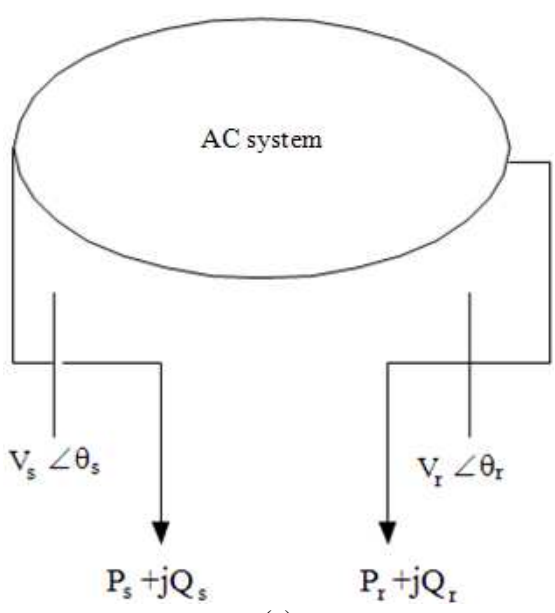

(c)

Fig. 1: Configuration of power system with HVDC transmission line system; (a) HVDC system; (b) Equivalent of HVDC system; (c) Successive HVDC model in power system

The ideal no load direct voltage is given by:

$$
\begin{aligned}
& \mathrm{V}_{\mathrm{dos}}=\left(\mathrm{V}_{\mathrm{ds}}+\mathrm{I}_{\mathrm{d}} \mathrm{R}_{\mathrm{C} 1}\right) / \cos \alpha \\
& \mathrm{V}_{\text {dor }}=\left(\mathrm{V}_{\mathrm{dr}}-\mathrm{I}_{\mathrm{d}} \mathrm{R}_{\mathrm{C} 2}\right) / \cos \gamma
\end{aligned}
$$

Here $\alpha$ and $\gamma$ are the ignition angle of converter I and converter II, respectively.

The average DC output voltage is given by:

$$
\mathrm{V}_{\mathrm{ds}}=\mathrm{V}_{\mathrm{dr}}+\mathrm{I}_{\mathrm{d}} \mathrm{R}_{\mathrm{L}}
$$

Here, $I_{d}$ is the DC line current.

The power factor $\phi$, fundamental line current lags the line voltage is written by: $\cos \varphi_{\mathrm{s}}=\mathrm{V}_{\mathrm{ds}} / \mathrm{V}_{\mathrm{dos}}$

$\cos \varphi_{\mathrm{r}}=\mathrm{V}_{\mathrm{dr}} / \mathrm{V}_{\mathrm{dor}}$

The real and reactive powers at the sending and receiving end are:

$\mathrm{P}_{\mathrm{s}}=\mathrm{V}_{\mathrm{s}} \mathrm{I}_{\mathrm{d}}$

$\mathrm{Q}_{\mathrm{s}}=\mathrm{P}_{\mathrm{s}} \tan \varphi_{\mathrm{s}}$

$\mathrm{P}_{\mathrm{r}}=\mathrm{V}_{\mathrm{r}} \mathrm{I}_{\mathrm{d}}$

$\mathrm{Q}_{\mathrm{r}}=\mathrm{P}_{\mathrm{r}} \tan \varphi_{\mathrm{r}}$

AC-HVDC fast decoupled power flow: The voltage magnitude, voltage angle and power flow of the AC-HVDC interconnecting equations must be coincident at the interconnecting point of the ACHVDC systems. The active and reactive power and the bus voltages to be supplied from the AC system are calculated using the specified initial value of DC system. The derived active and reactive power are incorporate into $\mathrm{AC}$ fast decoupled power to evaluate the unknown parameter at sending and receiving end bus as shown in Fig. 1c and given by:

$$
\begin{aligned}
& \Delta \delta_{\mathrm{s}}=-[\mathrm{B}]^{-1} \frac{\Delta \mathrm{P}_{\mathrm{s}}}{\mathrm{V}_{\mathrm{s}}} \\
& \Delta \delta_{\mathrm{r}}=-[\mathrm{B}]^{-1} \frac{\Delta \mathrm{P}_{\mathrm{r}}}{\mathrm{V}_{\mathrm{r}}} \\
& \Delta \mathrm{V}_{\mathrm{s}}=-\left[\mathrm{B}^{\prime \prime}\right]^{-1} \frac{\Delta \mathrm{Q}_{\mathrm{s}}}{\mathrm{V}_{\mathrm{s}}} \\
& \Delta \mathrm{V}_{\mathrm{r}}=-\left[\mathrm{B}^{\prime \prime}\right]^{-1} \frac{\Delta \mathrm{Q}_{\mathrm{r}}}{\mathrm{V}_{\mathrm{r}}}
\end{aligned}
$$

The procedure is repeated until all the relations interconnecting the AC-HVDC quantities are satisfied with sufficiently small errors.

\section{RESULTS}

The proposed method of fast decoupled power flow of power system with HVDC system is tested on the multimachine system as shown in Fig. 2. The HVDC system is equipped between bus 10 and bus 12 . The power system consists of 5 generators 18 buses. The proposed method achieved the output of power flow analysis. Table 1 shows the transmission line losses of the power system without HVDC system and with HVDC system. 


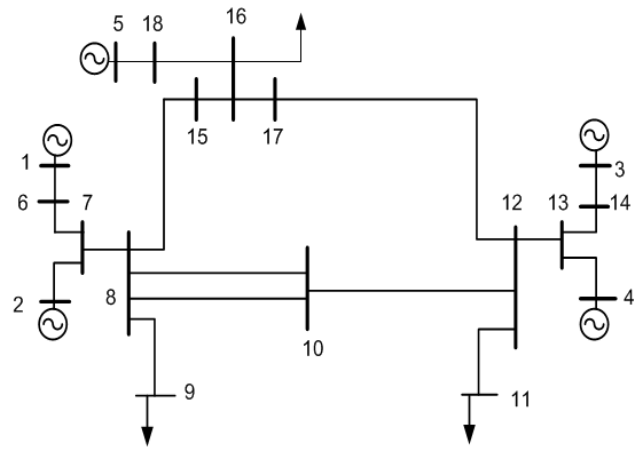

Fig. 2: Configuration of tested power system

Table 1: Transmission line losses of power system without HVDC and with HVDC

\begin{tabular}{llrlr}
\multicolumn{3}{c}{ and with HVDC } & \multicolumn{3}{l}{ With HVDC } \\
Line & Without HVDC & \multicolumn{2}{l}{---------- } \\
(between buses) & P & Q & P & \multicolumn{1}{c}{ Q } \\
\hline $1-6$ & 0.000 & 1.090 & 0.0000 & 1.066 \\
$6-7$ & 0.160 & 1.600 & 0.1590 & 1.555 \\
$2-7$ & 0.000 & 0.940 & 0.0000 & 0.931 \\
$7-8$ & 0.230 & 2.360 & 0.2340 & 2.318 \\
$8-10$ & 0.034 & -0.030 & 0.0400 & 0.017 \\
$8-9$ & 0.000 & 0.512 & 0.0000 & 0.509 \\
$10-12$ & 0.038 & 0.199 & 0.0020 & -0.180 \\
$11-12$ & 0.000 & 1.240 & 0.0000 & 1.110 \\
$12-13$ & 0.239 & 2.380 & 0.2050 & 2.030 \\
$13-4$ & 0.131 & 1.188 & 0.1307 & 1.266 \\
$13-14$ & 0.131 & 1.266 & 0.0000 & 0.789 \\
$3-14$ & 0.000 & 0.872 & 0.0000 & 0.789 \\
$8-15$ & 0.116 & 0.973 & 0.0860 & 0.678 \\
$15-16$ & 0.000 & 0.150 & 0.0000 & 0.109 \\
$16-17$ & 0.000 & 0.004 & 0.0000 & 0.010 \\
$17-12$ & 0.010 & -0.160 & 0.0190 & -0.110 \\
$16-18$ & 0.046 & 0.095 & 0.0460 & 0.091 \\
$5-18$ & 0.000 & 0.113 & 0.0000 & 0.113 \\
Total loss & 1.020 & 14.800 & 0.9180 & 13.220 \\
\hline
\end{tabular}

\section{DISCUSSION}

It can be seen from the simulation results that active and reactive power loss of power system without HVDC are around 1.02 and 14.80 p.u., respectively. However, with HVDC system, the active and reactive power loss is decreased to 0.918 and 13.22 p.u., respectively.

\section{CONCLUSION}

This study proposed the fast decoupled power flow analysis of power system with HVDC system. The HVDC power flow is specified and then the derived active and reactive power are incorporate into $\mathrm{AC}$ fast decoupled power to evaluate the unknown parameter at sending and receiving end.

The proposed method was tested on the multimachine system. It was found that the proposed method achieved the output of power flow analysis. It is shown from simulation results that HVDC not only can control power flow through the transmission line but also can decrease the transmission line loss.

\section{REFERENCES}

Ahmed, M.A., A.M. Haidar and A. Hussain, 2008. Vulnerability assessment of power system using radial basis function neural network and a new feature extraction method. Am. J. Applied Sci., 5: 705-713. DOI: 10.3844/ajassp.2008.705.713

Al-Abdulaziz, A.U., S.M. Bashi and A.A. Althubaiti, 2006. Analysis of the over-voltages produced by lightning strokes in the power transmission system in the southern region of Saudi Arabia. Am. J. Applied Sci., 3: 1755-1759. DOI: 10.3844/ajassp.2006.1755.1759

Al-Rawi, N.M., A. Anwar and A.M. Abdul-Majeed, 2007. Computer aided transient stability analysis. J. Comput. Sci., 3: 149-153. DOI: 10.3844/jcssp.2007.149.153

Augusto, L., P. Fernandes and A. Rocco, 2008. Electric power system under-voltage load shedding protection can become a trap. Am. J. Applied Sci., 6: 1526-1530. DOI: 10.3844/ajassp.2009.1526.1530

Avakian, S.K., A. Anwar and A.N. Abdalla, 2006. The application of agent technology on the power flow of Iraqi supper grid network. Am. J. Applied Sci., 3: 2174-2177. DOI: 10.3844/ajassp.2006.2174.2177

Federico, 2009. Continuous newton's method for power flow analysis. IEEE Trans. Power Syst., 24: 50-57. DOI: 10.1109/TPWRS.2008.2004820

Lu, C., J. Si, X. Wu and P. Li, 2006. Approximate dynamic programming coordinated control in multi-infeed HVDC power system. Proceeding of the IEEE PES Power Systems Conference and Exposition, Oct. 29-Nov. 1, IEEE Xplore Press, Atlanta, GA., pp: 2131-2135. DOI: 10.1109/PSCE.2006.296273

Noor, I., A. Wahab and A. Mohamed, 2008. Transient stability assessment of a power system using probabilistic network. Am. J. Applied Sci., 5: 1225-1232. DOI: 10.3844/ajassp.2008.1225.1232

Parry, M. and N. Gangatharan, 2005. Adaptive data transmission in multimedia networks. Am. J. Applied Sci., 2: 730-733. $\quad$ DOI: 10.3844/ajassp.2005.734.738

Sun, Y.Z., L. Peng, F. Ma, G.J. Li and P.F. Lv, 2008. Design a fuzzy controller to minimize the effect of HVDC commutation failure on power system. IEEE Trans. Power Syst., 23: 100-107. DOI: 10.1109/TPWRS.2007.913212 